ARTÍCULO

\title{
ESCRITOS Y SECCIONES DE MODA EN LA PRENSA YUCATECA \\ EL REFINAMIENTO DEL GUSTO Y LA SENSIBILIDAD ESTÉTICA DE LOS SEGUIDORES DE LAS MODAS EXTRANJERAS, 1840-1920
}

\author{
WRITINGS AND FASHION SECTIONS IN YUCATAN'S PRESS \\ FOREIGN FASHION ADHERENTS' REFINEMENT AND AESTHETICAL \\ SENSIBILITY, 1840-1920
}

\author{
Claudia Marcela VANegas DuRÁN \\ Universidad Nacional Autónoma de México \\ Instituto de Investigaciones Filológicas \\ Becaria posdoctoral \\ claitovanegas@gmail.com
}

Resumen

El artículo analiza una serie de escritos y secciones de modas publicados en la prensa yucateca desde 1840 hasta 1920. Los textos formaron parte de un discurso didáctico que pretendía refinar el gusto y la sensibilidad estética de los peninsulares. Sus escritores cumplieron la función de intermediarios culturales entre el atavío de moda en Europa y las prácticas locales al orientar a los lectores en el complejo y variable mundo de trajes y accesorios que comenzaban a comercializarse en las tiendas y talleres locales. Su contenido refleja cómo el uso de nuevos modelos fue una de las formas a través de la cual se materializaba la vida moderna y civilizada, lo que define a la indumentaria como uno de los dispositivos de distinción social y de orientación de los gustos, en particular de los grupos sociales de élite o aquellos que aspiran a serlo.

Palabras clave: intermediarios culturales; prensa; Yucatán; moda; atavío.

\begin{abstract}
The present article analyses an assortment of writings and fashion sections published by the Yucatan's press since 1840 to 1920. These texts were a part of a didactical discourse aimed to encourage refinement and aesthetical sensibility among Yucatan's people. The authors of these texts acted as cultural middlemen between European fashion and local customs by guiding readers in the multifarious and changing clothes and accessories offerings that began to be traded in local stores and workshops. The analyzed texts reveal how fashion was a way through which modern and civilized life got adopted, a fact that identify garments as a social and refinement distinction mark, particularly for elite groups or for those aspiring to become part of them.
\end{abstract}

Keywords: cultural middlemen; press; Yucatán; fashion; adornments.

Información del artículo

Recibido: 27 de agosto de 2019.

Aceptado: 27 de septiembre de 2019.

DOI: 10.22201/iih.24485004e.2020.59.70468 
Sin la novedad, a que somos tan afectos, no habría modas; y sin éstas el lujo sería de poco brillo entre nosotros.

La novedad crea la moda y sus preceptos; tan pronto como pasa la primera, pierde su prestigio la segunda. ${ }^{1}$

\section{Introducción}

El tema de este artículo es una de las aristas de una investigación más amplia que analiza la construcción de un código indumentario en Yucatán, desde la década de 1840 hasta comienzos de $1920,{ }^{2}$ a partir de los cambios y continuidades presentes en las prendas, adornos y estilos con los cuales los habitantes de la península ornamentaron sus cuerpos, y las mentalidades y comportamientos asociados a éstos. La elección de ese periodo, aparentemente tan amplio, cobra sentido cuando se recuerda que para esos años Yucatán estaba sufriendo una serie de cambios socioeconómicos asociados al auge económico agroexportador, primero con el azúcar y el ganado en la sierra (Tekax y Ticul), y de forma más significativa con el henequén a mediados del siglo xıx. Esta situación permitió a nuevos sectores consolidarse económicamente en la región, lo que a su vez promovió la búsqueda de mecanismos de distinción social que afianzarían el estilo y refinamiento que caracterizaría a la oligarquía local. Su capacidad económica dependía para unos de la explotación comercial de la producción agrícola, y para otros del comercio de exportación que daba mayores ganancias. Sobre todo entre los primeros la capacidad de endeudamiento, cuya garantía eran sus propiedades, cosechas y animales, jugó un papel muy importante al garantizarles un estilo de vida en el que el consumo de bienes importados, los espacios de socialización, viajes y actividades lúdicas fueron parte de su estatus y prestigio social que los integraba a la modernidad. ${ }^{3}$

1 “Modas”, El Museo Mexicano o Miscelánea Pintoresca de Amenidades Curiosas e Instructivas, t. 1, México, 1843, 541.

${ }^{2}$ Este artículo forma parte de la investigación "El atavío en Yucatán: del neoclásico a los fabulosos años veinte" llevada a cabo en el marco del Programa de Becas Posdoctorales de la Universidad Nacional Autónoma de México (UnAM), en el Instituto de Investigaciones Filológicas, asesorada por el doctor Mario Humberto Ruz Sosa. Agradezco los comentarios y sugerencias de los dictaminadores anónimos que me permitieron elaborar de forma más acertada algunas de las ideas trabajadas en este texto.

${ }^{3}$ Véanse, entre otros, Gladys N. Arana López, "Espacios, sujetos y objetos del habitar cotidiano en el México de entre siglos. Mérida la de Yucatán, 1886-1916”, Memoria y Sociedad 17, n. 3 (2013); Raquel Barceló, “La búsqueda del confort y la higiene en Mérida, 1860-1911”, 
De acuerdo con Bracamontes, esa etapa histórica representó para esta región el "nacimiento de un nuevo orden sustentado en la relación entre los amos y los sirvientes", ${ }^{4}$ el cual se traducía desde el punto de vista del atavío en un código indumentario que reflejaba una sociedad profundamente estratificada resultado de las herencias culturales del mundo maya y la colonización española, la influencia del sistema de la moda, el desarrollo de la industria henequenera y las ideas vinculadas a la búsqueda del progreso y la construcción del Estado nacional mexicano.

Para las élites yucatecas, que se movían entre los parámetros de la modernidad y los del antiguo régimen, el uso del atavío de moda los vinculaba con los modelos extranjeros asociados con la idea de civilización y modernidad. Al comprar bienes importados o consumir los elaborados localmente con materiales y patrones extranjeros se apropiaron de la moda, pues al llevar sobre sus cuerpos las últimas tendencias, en ocasiones con cierto retraso, se sentían modernos y hasta cierto punto europeos. Al mismo tiempo, la indumentaria permitió que se distinguieran a simple vista de aquellas personas que eran consideradas inferiores en el ámbito local. Como bien lo afirma Bauer, en el siglo xIx,

Una vez que la élite republicana dejó atrás la idea rural del prestigio para integrarse en un escenario urbano más homogéneo, fue necesario hacer un nuevo arreglo de posesiones para diferenciarse de los otros. La vestimenta y el adorno personal proporcionaban signos flexibles y portátiles de ese estatus. ${ }^{5}$

Vale la pena aclarar, sin embargo, que muchos de los preceptos de la moda no eran seguidos por los yucatecos al pie de la letra en el ámbito cotidiano; dichos preceptos pasaban por el filtro de La Habana, en donde la semejanza climática había reducido "el recargo de ropa" y se preferían "telas ligeras y transparentes a los terciopelos y merinos, incapaces de tolerarse en medio de un calor tropical, tan constante como excesivo, y que obliga a un sudor que en vano quiere contenerse con la cascarilla, ni con

en Historia de la vida cotidiana en México, v. 4, Bienes y vivencias. El siglo XIX, coord. de Anne Staples (México: El Colegio de México/Fondo de Cultura Económica, 2005); Pedro Miranda Ojeda, "La modernización de los parques en la ciudad de Mérida, Yucatán (1870-1910)", Letras Históricas, n. 3 (2010).

${ }^{4}$ Pedro Bracamontes y Sosa, Amos y sirvientes. Las haciendas de Yucatán 1789-1860 (Mérida: Universidad Autónoma de Yucatán, 1993), 3.

${ }^{5}$ Arnold J. Bauer, Somos lo que compramos. Historia de la cultura material en América Latina (México: Taurus, 2002), 207. 
remedio alguno". ${ }^{6}$ Llegados a Yucatán, como en todo proceso creativo y de agencia, las prendas podían sufrir modificaciones que dependían del gusto local (una estética propia), unas prácticas sociales y sin duda del poder adquisitivo de cada consumidor. Lo que podía ser calificado como común u ordinario en un contexto, al llegar a un espacio geográfico distinto podía adquirir otros significados y usos sociales. ${ }^{7}$

Para la sociedad decimonónica la forma en la que se vestía, cómo se cuidaba de las prendas, así como el correcto uso de éstas según la ocasión era, ante todo, una manifestación visible de la buena educación basada en virtudes morales fundamentales para guiar el comportamiento individual y colectivo. ${ }^{8}$ Toda esa serie de códigos implicaba la dedicación de tiempo, dinero y energías en el arreglo personal, definía la apariencia ideal del nuevo sujeto social que habitaría las ciudades y se integraría a un proyecto de nación moderno. Paralelo a esto, el sistema de la moda, cuyo eje era París, fue permeando a través de las rutas comerciales los hábitos indumentarios de las sociedades latinoamericanas, especialmente de las élites que vieron en las tendencias de materiales, trajes y accesorios elementos esenciales para destacarse y mantener jerarquías y relaciones de poder. La indumentaria está inmersa, entonces, en un proceso dinámico de aprendizaje, apropiación y adaptación que involucra al individuo y la sociedad.

Uno de los mecanismos a través de los cuales las personas se informaban de las últimas tendencias fue la prensa, tanto la de producción local como la internacional que llegaba a la península. El lenguaje del atavío y la moda progresivamente se fue ganando su espacio en revistas y periódicos a través de distintos formatos. Por un lado, estaban los relatos literarios que describían las costumbres y tipos considerados representativos de la sociedad peninsular de mediados del siglo XIX en los que sus autores registraban aprobación o crítica frente a ciertos hábitos indumentarios, muchos de ellos asociados a la influencia y uso de modas importadas. El segundo lugar lo ocuparían los artículos sobre las novedades de la moda como secciones

${ }^{6}$ Isidro R. Gondra, "La meridiana”, El Museo Mexicano o miscelánea Pintoresca de Amenidades Curiosas e Instructivas, t. 3, México, 1844, 130.

7 Andreia Martins, "Quimonos chinos y quimones criollos. La moda novohispana en el cruce entre Oriente y Occidente”, en La nao de China, 1565-1815. Navegación, comercio e intercambios culturales, ed. de Salvador Bernabéu Albert (Sevilla: Universidad de Sevilla, Secretariado de Publicaciones, 2013).

${ }^{8}$ Claudia Vanegas Durán, "Virtudes sociales y atavío en Yucatán a finales del siglo XIX y comienzos del xx”, Estudios de Cultura Maya, n. 53 (2019): 261-287, http://dx.doi. org/10.19130/iifl.ecm.2019.53.971. 
publicadas de forma regular que, a través de la palabra, y en algunas ocasiones de las imágenes, plasmaron un discurso que guiaba a los lectores en el complejo y variable mundo de trajes y accesorios. Por último estarían los anuncios publicitarios y secciones comerciales que daban cuenta de la gran variedad de productos que circulaban en la península, tanto de origen local como importados; esos anuncios muestran el progresivo desarrollo de la industria de la moda, el cual incluye a los talleres de oficios particulares como zapateros, sastres y sombrereros, y las tiendas misceláneas y especializadas.

En esta gran variedad de escritos se evidencia cómo el atavío está permeado de rasgos morales, éticos y estéticos, relaciones de poder, definición de géneros y cuerpos, identidades, inclusión y exclusión social, los lineamientos del sistema de la moda, la ocupación, los ingresos, entre otros, dando sentido a las prendas que llevaban los habitantes de la península. En este sentido, la moda "escrita", como la describe Julieta Pérez, "implica no sólo descripciones de trajes en determinadas ocasiones o temporadas, sino que se extiende a la expresión de una concepción, una postura o una valoración acerca de las modas". 9

Este artículo se centrará en el análisis del segundo tipo de textos publicados en una selección de revistas y periódicos yucatecos, desde 1840 hasta 1920, textos que forman parte de un discurso didáctico que pretendía refinar el gusto y la sensibilidad estética de los habitantes, especialmente citadinos, quienes copiaban y usaban modelos extranjeros vinculados al ideal de comportamiento elegante y de buen gusto del mundo moderno. Su contenido refleja cómo el uso de las tendencias en boga fue una de las formas a través de la cual se materializaba la vida moderna, lo cual define a la indumentaria como uno de los dispositivos de distinción social y de orientación de los gustos de las personas, y en particular de los grupos sociales de élite o que aspiraban a serlo y se guiaban por la exigencia cultural de las modas y sus representaciones simbólicas.

Las ideas plasmadas en los artículos reflejan cómo la moda se fue convirtiendo en una "exigencia cultural autónoma" 10 para un grupo de yucatecos, pues en ese tipo de artículos encontraban una guía que los orientaban en un mundo para muchos desconocido. Veamos, entonces, qué papel jugó

9 Julieta Pérez, "Antes de las secciones y revistas de modas... las modas en el Diario de México”, Nierika. Revista de Estudios de Arte, n. 11 (2017): 40.

${ }^{10}$ Gilles Lipovetsky, El imperio de lo efímero. La moda y su destino en las sociedades modernas (Barcelona: Anagrama, 1996), 30. 
la prensa dentro del sistema de la moda, cuál fue la intención, asuntos y particularidades de estos artículos de las secciones que tocaban el tema con el paso del tiempo y cómo pudieron influir en la forma en la que los lectores podían aprender, pensar y percibir el atavío.

\section{La prensa y el sistema de la moda}

Hablar de moda requiere, en primer lugar, hacer una breve aclaración sobre su significado. El término proviene del francés mode que puede referirse a una forma pasajera de hacer algo, una tendencia de la indumentaria, la industria dedicada a la fabricación de las prendas o un estilo de hacer o vivir. En el Diccionario de la lengua española, por su parte, se registran también varias acepciones: “Uso, modo o costumbre que está en boga durante algún tiempo, o en determinado país; gusto colectivo y cambiante en lo relativo a prendas de vestir y complementos; y conjunto de la vestimenta y los adornos de moda". ${ }^{11}$ Si nos guiamos por lo expuesto en el artículo "Modas" publicado en el Museo Yucateco en 1841, su significado depende de la persona a la que se le pregunte, pues mientras que un literato respondería que "es un uso que domina por un tiempo limitado, y que introduce en la sociedad el gusto, el capricho y la codicia", el petimetre objetaría argumentando que "es el auxilio que da el arte a las gracias personales según el gusto dominante”; un devoto, por su parte lo relacionaría con "el aliciente principal de que se vale el enemigo común de las almas para precipitarlas en el infierno”; el filósofo lo definiría como "la prueba más convincente de la inconstancia humana"; y para el sastre sería "una industria como cualquier otra". ${ }^{12}$

La moda es, como lo dejan ver estos primeros esbozos, un fenómeno complejo de la cultura humana que cobra sentido sólo si se le entiende como un proceso histórico de larga duración y se le analiza desde todas sus aristas (productiva, comercial, ecológica, social, psicológica, cultural). Las indagaciones que distintos investigadores sociales han realizado alrededor del tema y desde diferentes ópticas (psicología, filosofía, sociología, antropología, semiótica, historia y algunos enfoques interdisciplinarios) son el mejor lugar para comenzar a darle sentido a los significados hasta aquí

11 “Moda”, en Diccionario de la lengua española, versión electrónica 23.2 (2018), https:// dle.rae.es/?id=PTFxq8T.

12 “Modas”, Museo Yucateco. Periódico científico y literario, t. 1, Campeche, 1841, 306-307. 
expuestos y, en particular, a las manifestaciones sobre la práctica social de vestirse en Yucatán que analizaremos posteriormente.

Entre los investigadores interesados en definir la moda encontramos fundamentalmente dos posturas. Por un lado, están aquellos que utilizan el término sin confinarlo a una temporalidad y espacio determinados, es decir, quienes consideran que la moda hace referencia a las modificaciones que una persona realiza sobre una parte o totalidad del atavío y cómo éstas son imitadas por otros hasta convertirse en un estilo asociado a un cargo particular, un identidad, un oficio, entre otros. ${ }^{13}$ En este sentido, la moda se define a partir de dos componentes que orientan el dinamismo social y cultural del atavío en cualquier grupo humano: la novedad y la imitación. No importa, entonces, qué tan frecuentes sean los cambios vinculados a las modificaciones corporales, sino más bien cómo la decisión personal que un individuo toma en relación con lo que lleva puesto o sobre lo que usarán otros puede incidir en la vestimenta de los demás hasta el punto de convertirlo en un modelo a seguir.

Por el otro lado están aquellos que entienden la moda como un proceso histórico y geográfico que se inició a mediados del siglo XVI en las cortes europeas ${ }^{14}$ y se extiende hasta nuestros días con el desarrollo de la industria de la moda rápida (fast fashion) que produce millones de prendas al año bajo condiciones laborales cuestionables y consecuencias medioambientales irreparables. ${ }^{15}$ La observación de este fenómeno complejo en la larga duración le da sentido a la diversificación de formas y gustos que permean el atavío asociado a lo masculino y lo femenino, los tiempos, los lugares, las actividades realizadas, las profesiones, las edades, los grupos sociales, entre otros. Para Riello, el enfoque histórico permite entender el proceso que le ha dado

${ }^{13}$ Isabel Cruz de Amenábar, El traje. Transformaciones de una segunda piel (Santiago: Ediciones Universidad Católica de Chile, 1996), 30; Ruth Barnes y Joanne B. Eicher, comps., Dress and Gender: Making and Meaning (Oxford: Berg, 1992), 23, citado en Joanne Entwistle, El cuerpo y la moda. Una visión sociológica (Barcelona: Paidós, 2002), 55.

${ }^{14}$ Entwistle, El cuerpo y la moda...; Lipovetsky, El imperio de lo efímero...; Giorgio Riello, Breve historia de la moda. Desde la Edad Media hasta la actualidad (Barcelona: Gustavo Gili, 2016); Fernard Braudel, Las estructuras de lo cotidiano. Lo posible y lo imposible (Madrid: Alianza Editorial, 1984); Nicola Squicciarino, El vestido habla. Consideraciones psico-sociológicas sobre la indumentaria (Madrid: Cátedra, 1998); Daniel Roche, "La cultura material a través de la historia de la indumentaria”, en Historiografía francesa. Corrientes temáticas y metodológicas recientes, ed. de Hira de Gortari y Guillermo Zermeño (México: Comité Mexicano de Ciencias Históricas, 2000).

${ }^{15}$ Andrew Morgan, The true cost (Life Is My Movie Entertainment, 2015), $1 \mathrm{~h} 32 \mathrm{~m}$. 
forma a la moda a partir de las personas, sus acciones y pensamientos. La moda permite comprender la vida de las personas, "los 'modos', de los comportamientos y de las acciones cotidianas, no sólo de los que hacen moda o están de moda, sino de todos". Es entendida, desde esta perspectiva, como "una forma de cambio de vestuario en el tiempo", ${ }^{16}$ un tiempo que va de la mano del nacimiento y desarrollo del mundo moderno occidental.

Visto desde esta óptica la moda debe entenderse como un sistema que se ha ido configurando en la larga duración, cuyas características particulares, de acuerdo con Entwistle, son que "se encuentra en sociedades donde la movilidad social es posible; cuenta con sus propias relaciones de producción y consumo [...]; se caracteriza por una lógica de cambio regular y sistemático". ${ }^{17}$ Para Riello la moda es 1 ) un proceso de individualización y socialización, pues al mismo tiempo que los seres humanos desarrollan su particularidad se integran a la sociedad a través de la indumentaria como un elemento común; 2) una relación entre consumo y producción, pues la moda "no sólo se lleva y se consume, sino que se piensa, se crea, se produce, se vende y se difunde en los medios impresos y a través de las pantallas"; y 3) un medio de diferenciación de género que fue distinguiendo entre la ropa femenina y la masculina, y de edad al crear fracturas en el tiempo entre el pasado, el presente y el futuro con los cambios generacionales. ${ }^{18}$

En este sentido, sería más adecuado hablar de modas, pues es imposible hablar de una sola en procesos de circulación de mercancías que vinculan progresivamente distintos puntos del planeta y se integran en los ámbitos locales permeando a los grupos humanos con una intención de homogeneización, pero también de distinción social al integrarse con parámetros de clase. Esas modas viajeras, en palabras de Ruz,

contribuyen a modular con diversos signos actitudes tradicionales y gestos de siempre, otorgando nuevas fisonomías al paisaje humano y social; variando a veces los significantes sin alterar los significados, otorgando nuevos significados a añejos significantes o cambiando unos y otros para siempre. ${ }^{19}$

${ }^{16}$ Riello, Breve historia de la moda...

${ }^{17}$ Entwistle, El cuerpo y la moda..., 59.

${ }^{18}$ Riello, Breve historia de la moda...

${ }^{19}$ Mario Humberto Ruz, "Del quetzal a la tafeta. Atavío y comercio en la Alcaldía Mayor de Chiapa”, en Gestos cotidianos. Acercamientos etnológicos a los mayas de la época colonial (Campeche: Instituto de Cultura de Campeche/Universidad Autónoma de Campeche/Universidad Autónoma del Carmen/Instituto Campechano, 1997), 153. 
Los elementos que componen los atavíos están enmarcados, en este sentido, en un diálogo constante entre el individuo y la sociedad a la que pertenece, así como a transferencias culturales de ideas y formas, en un proceso de renovación y creación permanente. En la segunda mitad del siglo xIx y comienzos del $\mathrm{xx}$, cuando las prendas las confeccionaban los artesanos de la moda en sus talleres y las mujeres en los hogares, los estilos se creaban, se recreaban, se adaptaban, se modificaban, prestando atención a los detalles sutiles que dependían de materiales, técnicas, colores, accesorios, y las formas que significaban al cuerpo ideal. El atavío es, entonces, parte de una permanente combinación de elementos del pasado, del presente e incluso del futuro. Como bien lo anota Mercedes Urcelay en su artículo "Modas", publicado con el seudónimo Camilo Collazos,

Lentas son las evoluciones con que las modas se suceden unas a otras. La nueva no quita el cetro a la antigua, con la cara descubierta y frente a frente, sino que se introduce con cautela, a veces con engaño.

La moda nueva es esencialmente diplomática; todo lo reflexiona y gradúa. Primero se adapta a la antigua; luego la modifica atenuando sus exageraciones y extravíos; hoy quita un encaje, mañana sustituye una tela con otra novísima, suplanta el color favorito con alguno de tono más serio (la última palabra de la elegancia) da más relieve a algunos preciosos y tímidos detalles; llama en auxilio un dije del siglo pasado; inventa algo enérgico, atrevido, típico; y con tantos y variados elementos forma su propia vida, su brillante reinado que por cierto dura... l'espace d'un matin. ${ }^{20}$

La península de Yucatán no estuvo exenta de ser parte de este fenómeno global. Materias primas y accesorios importados poco a poco fueron llegando a las tiendas locales, especialmente las de Mérida que, a finales del siglo xIx y comienzos del $\mathrm{xx}$, ofrecían una gran variedad de productos asociados a la experiencia de vestirse a la moda, no sólo la de influencia extranjera, sino la que se fue construyendo regionalmente. La imitación y adaptación de parámetros de origen extranjero requirió de intermediarios culturales vinculados a una industria en pleno crecimiento que integraba a la producción de materias primas, prendas, adornos y accesorios con los artesanos de la moda y la imagen (modistas, sastres, peluqueros, barberos, comerciantes, escritores, entre muchos otros) quienes guiaban a

${ }^{20}$ M. Urcelay, “Modas”, Álbum Literario, Científico de Artes y de Modas, 1891, 46. 
los consumidores en un mundo que se estaba construyendo alrededor del consumo, la novedad y la necesidad de cambio. ${ }^{21}$

La prensa jugaría un papel muy importante en ese proceso en el ámbito mundial. Al igual que en otras partes del planeta, las revistas y periódicos mexicanos, especialmente desde la segunda mitad del siglo xix y comienzos del xx, fueron órganos de difusión que complementarían lo que sucedía en la esfera comercial y el desarrollo de tiendas especializadas en todo lo referente a la indumentaria de hombres y mujeres. El sistema de la moda, además de crear estilos novedosos, produce "ideas estéticas que sirven para estructurar la recepción y el consumo" permanente de estilos; ${ }^{22}$ razón por la cual requiere de "espacios en los que mostrarse, contemplarse y comprarse, y debe representarse en libros, revistas, imágenes, etcétera”. ${ }^{23}$ En Europa, desde finales del siglo XviII, la moda "es algo para imaginar, a lo que aspirar o sobre lo que discutir"; ${ }^{24}$ la moda escrita en ese sentido se fue apropiando de diversos espacios del mundo de los impresos.

La manera en la que fueron anunciadas las mercancías ofrecidas por comerciantes y artesanos en Yucatán, así como las descripciones plasmadas en las secciones de moda muestran cómo no sólo se trataba de vender, sino de crear hábitos de consumo asociados a valores relacionados con un ideal de país moderno y civilizado. ${ }^{25} \mathrm{Al}$ igual que otras zonas de México, el fenómeno social de la moda progresivamente se fue ganando su espacio en las publicaciones locales al incluirse notas esporádicas, imágenes o relatos literarios y secciones periódicas que aludían al tema al señalar "sus orígenes, implicaciones, costos, excesos, usos y todo aquello que definía su significado". ${ }^{26}$

En ese sentido, nos cobijamos en la afirmación de Ruth Atilano cuando destaca cómo

${ }^{21}$ Este propósito pedagógico también se hace evidente en los relatos literarios que describen las costumbres y tipos considerados representativos de la sociedad peninsular de mediados del siglo XIX, publicados en revistas y periódicos locales.

${ }^{22}$ Entwistle, El cuerpo y la moda..., 60.

${ }^{23}$ Riello, Breve historia de la moda...

${ }^{24}$ Riello, Breve historia de la moda...

${ }^{25}$ Ruth Yolanda Atilano Villegas, "La moda como práctica cultural y social en la prensa del Porfiriato: El mundo (1894-1899); y El mundo ilustrado (1900-1914)” (tesis de maestría, Universidad de Guanajuato, 2016), 12.

${ }^{26}$ Dolores Armendáriz, "La concepción de la moda en México durante el siglo xix y principios del siglo xx”, Nierika. Revista de Estudios de Arte, n. 11 (2017): 28. 
La prensa posee una naturaleza multifactorial, que denota sus funciones en la sociedad; en primer lugar, es un producto cultural que se gesta en el contexto de una sociedad específica; en segundo, es una fuente de información sobre la vida cotidiana de dicho conglomerado en sus múltiples aspectos; en tercero, es un vehículo de encuentro social, en el que se encuentran los miembros de una colectividad; en cuarto lugar, es un agente de cambio social, gracias a la propagación de las corrientes de opinión; finalmente, constituye un instrumento para la memoria de una sociedad, ya que da cuenta de su propia historia al recoger el pensamiento de su época en todo su contenido; finalmente, también es un bien de consumo que da prestigio social. ${ }^{27}$

A continuación, exploraremos algunas secciones y artículos de moda publicados en la prensa yucateca, para presentar los primeros indicios que se tienen sobre quiénes eran sus autores, qué críticas expresaron alrededor de los usos locales que adoptaron y adaptaron códigos cercanos a otros valores culturales, y cómo estos escritos fueron un medio para la divulgación, conocimiento y aprendizaje sobre las novedades en asuntos indumentarios.

\section{Los redactores de moda y sus objetivos}

En la península de Yucatán, quienes escribían y financiaban las publicaciones periódicas pertenecían a unas pocas familias, una élite intelectual, económica y política ${ }^{28}$ que seleccionaba la información que consideraba relevante según su línea editorial. La mención a otros miembros de la sociedad es esporádica y se realiza desde la perspectiva de una élite que denigra las prácticas culturales de quienes eran considerados como inferiores, incivilizados o carentes de interés, y destaca aquellas que pueden estar más cercanas a un código de comportamiento ideal o tienen la posibilidad de ser integradas a su proyecto de nación.

Durante el periodo analizado, entre sus propósitos estaba el de contribuir a la conformación de un país imaginado con nuevos valores asociados a la modernidad y la civilización; razón por la cual este tipo de publicaciones inevitablemente es más generosa en temas de interés para la élite local

27 Atilano, "La moda como práctica cultural y social...", 22.

${ }^{28}$ Marcela González Calderón, "La imprenta en la península de Yucatán en el siglo XIX" (tesis doctoral, Centro de Investigación y Estudios Superiores en Antropología Social, 2014), 11. 
que, en nuestro caso de estudio, hacen referencia, entre otros temas, a espacios de socialización exclusivos, códigos de conducta y anuncios que apuntaban a un público consumidor de productos específicos. ${ }^{29}$

Dentro de la amplia variedad de publicaciones hemerográficas consultadas hasta el momento para el contexto yucateco, aquéllas en las que se han encontraron artículos o secciones dedicadas a la moda son las siguientes: Museo Yucateco. Periódico Científico y Literario (1841-1842); El Museo Mexicano o Miscelánea Pintoresca de Amenidades Curiosas e Instructivas (1843-1844); El Liceo Mexicano (1844); La Guirnalda. Periódico Literario Redactado por una Sociedad de Jóvenes (1860); Biblioteca de Señoritas. Lecturas del Hogar (1868); El Recreo del Hogar (1879); Álbum Literario, Científico de Artes y de Modas (1891); Pimienta y Mostaza. Periódico Literario, de Espectáculos y Variedades (1893); y Adelante. Seminario Ilustrado de Literatura, Artes y Ciencias (1917). A excepción de El Museo Mexicano y El Liceo Mexicano todos los demás fueron publicados en Mérida.

A la par de lo que se escribía e imprimía en la península, los yucatecos también tuvieron acceso a títulos extranjeros como La Moda Elegante Ilustrada. ${ }^{30}$ Fue una de las publicaciones seriadas españolas de este tipo de más larga trayectoria (de 1842 a 1927). Su primer número se imprimió en Cádiz en 1842 con el título La Moda. Revista Semanal de Literatura, Teatro, Costumbres y Modas, cuyo fundador fue el ingeniero, médico y escritor gaditano Francisco Flores Arenas (1801-1877). Poco tiempo después fue adquirida por Abelardo de Carlos y Almansa (1822-1884), uno de los más reconocidos empresarios de la prensa ibérica del siglo xix. En la década de 1860 no sólo cambiaría su título al de La Moda Elegante Ilustrada. Periódico de las Familias, sino que se comenzaría a imprimir en Madrid; más adelante su subtítulo fue Periódico de Señoras y Señoritas. El contenido que ofrecía era, entre otros, figurines iluminados de las modas de París, novelas, crónicas, bellas artes y música. ${ }^{31}$

Para esos años en la ciudad de México también se publicaron varias revistas y periódicos cuyo público principal fueron las mujeres. Entre otros

${ }^{29}$ Existen varios trabajos que han destacado la importancia de la moda en la prensa mexicana de la época, entre otros pueden consultarse a Atilano, "La moda como práctica cultural y social...”; Dolores Armendáriz, "La concepción de la moda en México...”; Pérez, "Antes de las secciones y revistas de modas...".

${ }^{30}$ González, "La imprenta en la península de Yucatán...”, 224.

${ }^{31}$ La Moda Elegante, n. 1, en Hemeroteca Digital de la Biblioteca Nacional de España, http://hemerotecadigital.bne.es/details.vm?q=id\%3A0004782809\&lang=es. 
podemos mencionar el Semanario de las Señoritas Mejicanas. Educación Científica, Moral y Literaria del Bello Sexo (1840-1842); el Panorama de las Señoritas, Periódico Pintoresco, Científico y Literario (1842); El Presente Amistoso. Dedicado a las Señoritas Mexicanas por Cumplido (1847); La Semana de las Señoritas Mejicanas (1851); La Camelia. Semanario de Literatura, Variedades, Teatros, Modas, etc. Dedicado a las Señoritas Mejicanas (1853); El mundo (1894-1899); y El mundo ilustrado (1900-1914). ${ }^{32}$ Su contenido era variado y tenía como propósito contribuir a la instrucción informal de las mujeres. Los editores incluyeron lecturas literarias, científicas, religiosas, morales, sobre modas y "labores propias de señoras" (recetas de cocina, economía doméstica, cuidado de los niños), partituras musicales y anuncios comerciales. Por el momento desconocemos si alguno de estos periódicos fue leído por las yucatecas durante esos años, pero su existencia destaca el interés común sobre la educación de las mujeres, el cual compartían las publicaciones peninsulares con las de otros contextos culturales.

Ahora bien, la prensa como fuente de información tiene ciertas limitaciones que es importante tener en cuenta, pues muchos periódicos y revistas tuvieron una vida muy corta y los ejemplares conservados en los acervos de bibliotecas y hemerotecas desafortunadamente no siempre dan cuenta de su vida social, es decir, el periodo cabal en el que fueron publicados. A pesar de esto, la variedad, no sólo temática sino temporal, de los periódicos consultados ha permitido dar cuenta de algunos de los temas que inquietaban a la sociedad yucateca con el pasar de las décadas. Las lecturas analizadas permiten ver el interés que existía por el tema de la moda y cómo el espacio de los impresos periódicos fue parte importante del desarrollo del sistema de la moda en el ámbito local. Además, como se verá, se creó un grupo reducido de personas que escribían sobre el tema sin ser especialistas, y que iban más allá de la simple descripción de las prendas, contribuyendo desde el lenguaje escrito a la construcción de un imaginario sobre la moda.

La mayor parte de éstos se refieren a la moda femenina y en contadas excepciones encontramos algunas notas sobre el atuendo masculino. Como se verá a lo largo de este artículo la asociación entre moda y mujer fue una construcción social que identificó el arreglo personal con conceptos como

32 Atilano, "La moda como práctica cultural y social..."; Rodrigo Antonio Vega y Ortega, “Moral científica para el 'bello sexo' en la prensa mexicana para mujeres (1840-1855)", Nuevo Mundo Mundos Nuevos, 2010, http://journals.openedition.org/nuevomundo/ pdf/60082. 
superficialidad, banalidad, capricho y futilidad válidos, desde el punto de vista de algunos escritores, sólo para el mundo femenino, para el llamado "sexo débil" o "bello", aunque siempre dentro de una justa medida. Sin embargo, siguiendo a Riello, "la historia de la segunda mitad del siglo xIX y primera mitad del siglo xx demuestra que la moda, quizá precisamente porque se hace mujer, se convierte en algo complejo y se vuelve fascinante". ${ }^{3}$ No hay duda de que los intermediarios culturales de la moda - prensa y escritores especializados, pequeñas y medianas industrias o talleres asociados a la producción de telas y manufactura de ropa y accesorios, así como los comerciantes y almacenes- se enfocaron más en el atavío de las mujeres, pues es allí donde los cambios se hacen más visibles, los detalles en las formas, los tonos, los ornamentos renuevan las prendas constantemente en busca de la novedad y de un ideal femenino dinámico que se ajusta a las actividades lúdicas y profesionales en las que se van desenvolviendo sus vidas cotidianas.

Si bien es cierto que en este tipo de secciones se observa una aparente ausencia de la moda masculina ${ }^{34}$ y del interés que los varones pudieran tener en el tema, en la publicidad y textos relacionados con el ideal masculino se destacaba la importancia de la apariencia personal y el buen gusto como parámetros que guiaban al hombre moderno o que se preciaba de serlo. El desarrollo de tiendas, talleres de oficios y la publicidad asociada a estos espacios y los productos que vendían muestran el interés y las demandas existentes alrededor del atavío masculino en el marco del sistema de la moda y su vinculación con el desarrollo de nuevas prácticas sociales y modelos extranjeros.

Los escritores y escritoras cumplieron la función de intermediarios culturales entre un atavío de moda de origen foráneo y las prácticas locales. Eran considerados por los lectores, en este sentido, como autoridades en la materia, aunque ellos mismos no se presentaban siempre como tales. Sus crónicas y descripciones eran fuentes de información que aconsejaban a los consumidores locales sobre las tendencias y los errores que se cometían o debían evitarse a la hora de usarlas. A través de sus páginas, además, se establecía un encuentro social entre personas que compartían ciertos intereses, prácticas e ideales. ${ }^{35} \mathrm{Si}$ bien es cierto que cada autor con su estilo particular plasmaba ideas personales y un propósito particular, su discurso

\footnotetext{
${ }^{33}$ Riello, Breve historia de la moda...

${ }^{34}$ Lipovetsky, El imperio de lo efímero..., 39.

35 Atilano, "La moda como práctica cultural y social...", 23.
} 
refleja su contexto social de producción, es decir, la sociedad a la cual pertenece quien escribe y el público al que se dirige la publicación seriada.

Identificar quiénes eran los autores de los artículos sobre modas no es sencillo. Muchos de los textos son anónimos y otros son firmados con seudónimos que no hemos logrado identificar como Asmodéo y Juan Soplillo en el Liceo Mexicano o Zafiro en Pimienta y Mostaza. Entre los que firman encontramos al poeta y abogado Mariano Esteva y Ulibarri (1827-1857); a Ildefonso Estrada y Zenea que desconocemos si es el pedagogo, periodista, editor, orador, dramaturgo, impresor e historiador homónimo de origen cubano (1826-1911) que se radicó en México en la década de $1870^{36}$ y cuyo libro Diccionario de los niños fue publicado en Mérida; ${ }^{37}$ a Apolinar García García autor de la Historia de la Guerra de Castas de Yucatán (1865); al obispo Crescencio Carrillo y Ancona (1837-1897) con el seudónimo Carlos Ril; ${ }^{38}$ a la poetisa Mercedes Urcelay bajo el nombre de Camilo Collazos; ${ }^{39} \mathrm{y}$ a Beatriz Peniche de Ponce (1893-1976), escritora, maestra y feminista mexicana yucateca.

Aquellos que escribieron sobre el atavío con cierta continuidad, dado que se creó una sección especial dentro de las publicaciones, aunque no con una periodicidad precisa, fueron Mariano Esteva y Ulibarri que firmaba con el seudónimo de Querubín los artículos “Modas” de El Liceo Mexicano (1844); Zafiro que redactaba la sección "Para las damas" de Pimienta y Mostaza. Periódico Literario, de Espectáculos y Variedades, cada quince días, de abril a agosto de 1893 (figura 1); y Beatriz Peniche de Ponce quien lo hacía en la "Página de las damas" de Adelante. Seminario Ilustrado de Literatura, Artes y Ciencias (1917) (figura 2). En el caso del Álbum Literario, Científico de Artes y de Modas, a pesar de que su título anunciaba que trataría el tema, sólo aparecieron lecturas de forma esporádica en el primer año de la revista (números 1, 6 y 7) a cargo de Camilo Collazos (Mercedes Urcelay). Los restantes

${ }^{36}$ Horacio Guadarrama Olivera, "Idelfonso Estrada y Zenea: un intelectual cubano en el puerto de Veracruz, 1871-1872”, Sotavento 4, n. 8 (2000).

${ }^{37}$ Ildefonso Estrada y Zenea, Diccionario de los niños. Contiene pensamientos, máximas, consejos e instrucciones relativas a la educación de la juventud, con indicación de las reglas de urbanidad y buenas maneras para la vida social y noticias sobre los más importantes descubrimientos en las ciencias, las artes y las letras (Mérida: Imprenta El Iris de I. E. y Z., 1869).

${ }^{38}$ Juana Manrique de Lara, Seudónimos, anagramas, iniciales, etc., de autores mexicanos y extranjeros (México: Secretaría de Educación Pública, 1943), 17.

${ }^{39}$ Juan Duch, Yucatán en el tiempo. Enciclopedia alfabética (Mérida: Inversiones Cares, 1998), 37. 


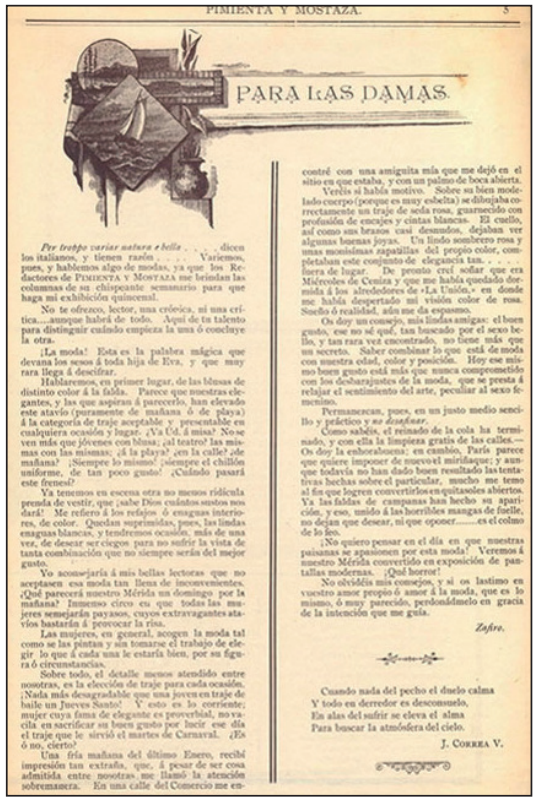

Figura 1. "Para las damas", Pimienta y Mostaza. Periódico Literario, de Espectáculos y Variedades, Mérida, 23 de abril de 1893, año II, n. 29, 5

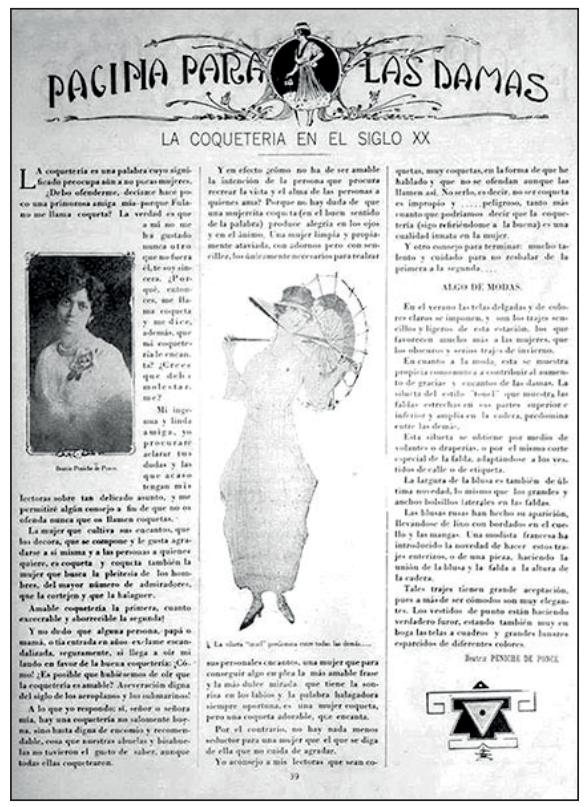

Figura 2. "Página para las damas", Adelante. Seminario Ilustrado de Literatura, Artes y Ciencias Mérida, 30 de junio de 1917, v. 1, n. 2, 39

autores revisados preparaban contribuciones esporádicas que presentaban alguna crítica sobre el uso y apropiación de las novedades del atavío.

El uso de seudónimos fue común para esos años. El caso de Mercedes Urcelay nos parece significativo, pues si bien para finales del siglo xIX ya muchas mujeres escribían en la prensa local, firmaba sus notas sobre moda con un seudónimo masculino, como una forma de crear controversia entre las "elegantes lectoras", pues ella misma señalaba que al no ser "alguna señora que escribe sobre tema tan sabroso en alguna publicación extranjera, harán un mohín desdeñoso" de las líneas que redactaba. Más adelante expresaba que "tengo en gran estima a mi sexo feo y adoro mi calidad de hombre [...]. Porque, pueden creerlo, lo que más me entusiasma, lo mejor, la obra más artística, más bella, más acabada y perfecta de la creación, es una mujer; bella se entiende" ${ }^{40}$. Sus textos eran, entonces, el espacio para

${ }^{40}$ Mercedes Urcelay, "Modas”, Álbum Literario, Científico de Artes y de Modas, t. 1, n. 1, Mérida, 15 de agosto de 1891, 7. 
expresar sus ideas sobre el "poder femenino" y otros temas sobre los que deseaba que se prestara atención, pero como si lo dijera un hombre.

Es significativo tener entre los escritores del atavío a hombres y mujeres, pues nos brinda la oportunidad de contrastar los propósitos y temas sobre los que prestaban atención unos y otras, además de que se observan algunos cambios asociados al paso del tiempo. Detrás de sus textos podemos encontrar un estilo propio que le daba sentido a lo que cada uno consideraba digno de ser plasmado en unas cuantas páginas o párrafos dedicados al atavío. En general, prestaban menos atención a las descripciones detalladas de las prendas y más bien se dedicaban a reflexionar sobre lo que observaban en sus círculos sociales, el comercio, los talleres y el sistema de la moda en general.

Algunos de ellos reflexionaban sobre el oficio que desempeñaban. Mariano Esteva y Ulibarri, en la década de 1840, se proponía brindar en sus textos una "relación de cuanto haya de nuevo en París, adaptable en México"; aclaraba a sus futuras seguidoras que estaba consciente de que la tarea que había decidido emprender le podía traer "graves disgustos con las bellas" por ser un hombre. Consideraba que como escritor de modas debía limitarse a "indicar los vestidos, las telas, los adornos propios de cada estación, ser, por decirlo así, un termómetro del gusto, sin meterme a calificarlo y sin hablar sobre todo de los sentimientos y de las personas". ${ }^{41}$ Zafiro, por el contrario, advertía a las yucatecas que "no es de las modas de París, en absoluto, de lo que quiero hablar, es más bien poneros de relieve ciertos inconvenientes que cometéis, [...] al copiar no sólo los trajes sino los usos y costumbres de otros países que dan la norma de lo que la civilización adopta e impone". ${ }^{42}$ El proceso dinámico del sistema de las modas encontró en la prensa un espacio para su divulgación; pero como lo sugirió un autor de la época, al existir modas buenas, modas malas e indiferentes las revistas y periódicos cumplieron un papel importante al seleccionar y guiar a mujeres y hombres en la identificación de las apropiadas, aquellas que "proporcionan comodidad sin faltar a las leyes del buen gusto". ${ }^{43}$

Dentro de este orden de ideas, fue importante para estos redactores de moda presentar cuáles eran sus fuentes de información; unos destacaban

${ }^{41}$ Mariano Esteva y Ulibarri, “Modas”, El Liceo Mexicano, t. 2 (México: José Mariano Lara, 1844), 304.

${ }^{42}$ Zafiro, "Para las damas", Pimienta y Mostaza. Periódico Literario, de Espectáculos y Variedades, Mérida, 21 de mayo de 1893, año II, n. 33, 4.

43 “Modas", Museo Yucateco. Periódico Científico y Literario, t. 1, Campeche, 1841, 307. 
ser observadores de primera mano de las últimas tendencias de París ${ }^{44}$ otros como Esteva y Ulibarri acudían a sastres, modistas, comerciantes y joyeros quienes les mostraban las últimas adquisiciones, figurines y periódicos importados; Urcelay visitaba las tiendas y observaba a sus congéneres; García Montero, por su parte, copiaba la descripción de un traje de baile que aparecían en el "periódico de las novedades elegantes destinado a las señoras y señoritas" del Correo de Ultramar. ${ }^{45}$ Incluir estas aclaraciones legitimaba el contenido de sus artículos, pues la mayoría de ellos carecían de imágenes que de forma visual señalaran las formas de los trajes. La iconografía daba "a conocer materialmente los usos" 46 de las descripciones escritas de las prendas. Mariano Esteva y Ulibarri y Juan Soplillo referían los materiales, formas y detalles en un intento de traducir el complejo lenguaje de la moda y las tendencias que los figurines que acompañaban sus textos presentaban. Soplillo, por ejemplo, de uno de los trajes (figura 3) decía "mayor complicación en el peinado, gola a la Pompadour, rosa y lazo de listón, tuniseta de crespón o gasa, de color claro o blanca, flores y cenefa bordadas, fondo de raso, y manga tan corta, como prolongado el pico del corpiño o peto, a cuya sutil agudeza tiempo es ya de que la Moda diga como Dios al mar: de aquí no pasarás". ${ }^{4}$

Para Beatriz Peniche de Ponce, quien escribió a comienzos del siglo xx, pareciera que los bocetos (figura 4) no requerían mayor explicación. Como si éstos hablaran por sí mismos, pues de alguna forma, siguiendo a Ortiz este tipo de imágenes "constituyen un lenguaje visual con fines de comunicación universal o, al menos, pretendidamente homogeneizada, que recurre a la iconicidad y al signo como factor semiótico de mayor eficacia que las palabras". ${ }^{48}$ En el caso de Peniche los figurines sirvieron como respaldo para dar sugerencias sobre posibles alteraciones en las telas y detalles de acuerdo al gusto y usos del contexto local, lo que refleja una de las vías a través de la cual se visibiliza el proceso de adaptación creativo que permea el atavío. Con la siguiente cita quedará más clara la idea que queremos destacar:

44 “Modas”, Museo Yucateco. Periódico Científico y Literario, t. 1, Campeche, 1841, 307.

${ }^{45}$ García Montero, "La moda”, Biblioteca de Señoritas. Lecturas de Hogar (Mérida: Imprenta de Rafael Pedrera, 28 de noviembre de 1868, Primera Serie, Entrega 11), 83.

${ }^{46}$ Mariano Esteva y Ulibarri, “Modas”, El Liceo Mexicano, t. 2 (México: José Mariano Lara, 1844), 23.

${ }^{47}$ Juan Soplillo, “Modas”, El Liceo Mexicano, t. 1 (México: José Mariano Lara, 1844), 120.

${ }^{48}$ Julieta Ortiz, Imágenes del deseo. Arte y publicidad en la prensa ilustrada mexicana (1894-1939) (México: Universidad Nacional Autónoma de México, Coordinación General de Estudios de Posgrado, 2003), 13. 


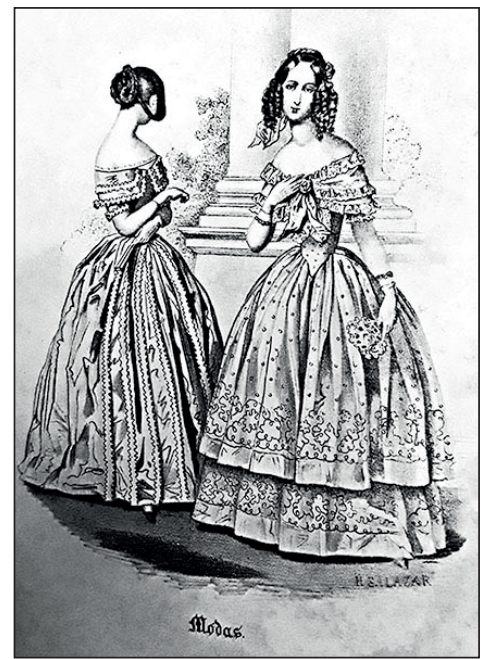

Figura 3. Juan Soplillo, "Modas", El Liceo Mexicano, t. 1, 1844, 120
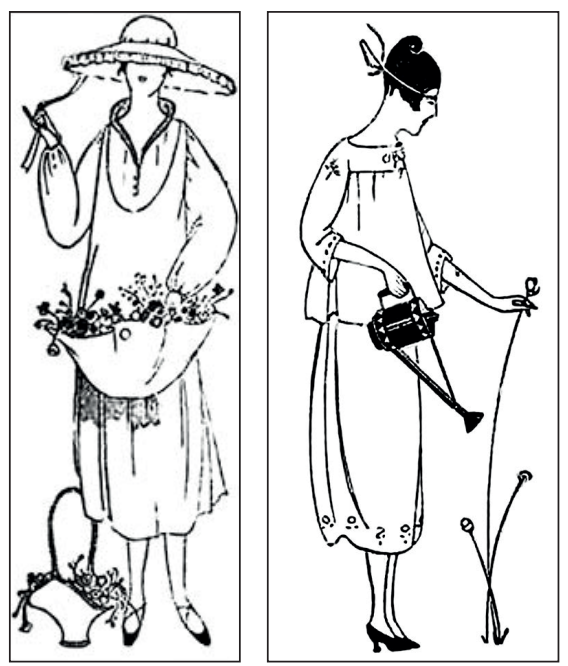

Figura 4. Adelante. Seminario Ilustrado de Literatura, Artes y Ciencias 1, n. 12

(Mérida, 8 de septiembre de 1917), 255

Presento a mis lectoras dos encantadores modelos de la estación, tan artísticos cuando prácticos. Aquí en este país, donde el ama de casa, aun la más afortuna$\mathrm{da}$, tiene necesidad de atender materialmente el menaje, es menester usar trajes sencillos, pero con esa coquetería que no consiste en riqueza de telas ni rebuscamiento de corte sino en la propiedad y en la gracia de la línea. Ambos trajes pueden confeccionarse en cualquier tela color unido: desde el lino hasta el "Vichy".

El modelo guarnecido con flores las podría llevar recortadas de una cretona con una cadenilla alrededor o bordadas con algodón al pasado. También podría ser a punto de cruz, esa industria yucateca tan primorosa. En los Estados Unidos se estima mucho esta labor. El delantal, cuya enorme bolsa está desbordando flores, puede servir para los enseres de limpieza o de costura.

Admirase en ambos modelos una perfecta delicadeza de líneas. ${ }^{49}$

De acuerdo con Atilano, las mujeres en las secciones de moda encontraban pautas para "ejercitar su imaginación con respecto a sus trajes". ${ }^{50}$ Las imágenes y descripciones incluidas en la prensa, el comercio local, las casas de modas y los eventos sociales les brindaban los elementos para

${ }^{49}$ Beatriz Peniche de Ponce, "Páginas para las damas", Adelante. Seminario Ilustrado de Literatura, Artes y Ciencias, Mérida, 8 de septiembre de 1917, v. 1, n. 12, 255.

${ }^{50}$ Atilano, "La moda como práctica cultural y social...", 13. 
inspirarse para crear un estilo sin salirse de los parámetros de la moda, o al menos eso intentaban. En este sentido el atavío se redefine culturalmente y se pone en uso. ${ }^{51}$ A finales del siglo xix, Zafiro criticaba a las mujeres de la sociedad yucateca porque "en general, acogen la moda tal como se las pintan y sin tomarse el trabajo de elegir lo que a cada una le estaría bien, por su figura o circunstancia". ${ }^{2}$ De tal suerte que el acto de vestirse se define, en este sentido, entre dos vertientes, una irreflexiva y la otra consciente y reflexiva; en ambos casos lo individual y lo colectivo están en un permanente diálogo: "El sistema de la moda proporciona la 'materia prima' de nuestras elecciones, pero éstas se adaptan dentro del contexto de la experiencia vivida de la mujer, de su clase, raza, edad, ocupación, etcétera." 53

Para los redactores de modas ese espacio se convirtió en una forma de erradicar de las y los yucatecos hábitos considerados como erróneos. Carrillo y Ancona, por ejemplo, incluyó una trova del predicador fray Gerundio de Campazas sobre el malakoff, ${ }^{54}$ con el propósito de ilustrar a sus lectoras sobre sus inconvenientes, para que "pueda haber en los templos más espacio para la pobre gente que no usa de esa moda, y los predicadores tengan mayor número de oyentes". ${ }^{55}$ Zafiro, por su parte, usaba su sección para decir, sin rodeos, cuáles eran las incorrecciones que cometían las yucatecas a la hora de vestirse. Quería levantar ampolla para que se grabara en los cerebros de las lectoras “y curar por ese medio 'algo salvaje', pero práctico y seguro, ciertos males casi crónicos”. ${ }^{56}$ Lo defendió como un

${ }^{51}$ Igor Kopytoff, "La biografía cultural de las cosas La mercantilización como proceso", en La vida social de las cosas. Perspectiva cultural de las mercancías, ed. de Arjun Appadurai (México: Grijalbo, 1991), 93.

52 Zafiro, "Para las damas", Pimienta y Mostaza. Periódico Literario, de Espectáculos y Variedades, Mérida, 23 de abril de 1893, año II, n. 29, 5.

${ }^{53}$ Entwistle, El cuerpo y la moda..., 47.

${ }^{54}$ En Yucatán el término malakoff fue de uso común y se refería a la estructura rígida que tenía el propósito de ahuecar las faldas, y que para la época se llamaba también crinolina. Este nombre se le da a la prenda a la par de la batalla de Malakoff (o batalla de Malájov), entre los ejércitos de Francia y Rusia el 7 de septiembre de 1855, que ganarían los primeros. El nombre trascendería las fronteras francesas, llegando a conocerse en algunos contextos españoles y de América. Véase Diana Fernández, "Malakoff o crinolina. La actualidad política y la moda”, Vestuario escénico, 2015, https://vestuarioescenico.wordpress.com/2015/03/16/ malakoff-o-crinolina-la-actualidad-politica-y-la-moda/.

55 Crescencio Carrillo y Ancona, “Apuntes históricos sobre el Malakoff”, La Guirnalda. Periódico Literario Redactado por una Sociedad de Jóvenes, 1860, 143.

56 Zafiro, "Para las damas", Pimienta y Mostaza. Periódico Literario, de Espectáculos y Variedades, Mérida, 23 de abril de 1893, año II, n. 29, 5. 
método efectivo porque luego de haber publicado una crítica mordaz contra el uso de ciertas blusas, que eran de distinto color al de la falda y además se llevaban en toda ocasión, afirmaba que casi había desaparecido su uso entre las mujeres por vergüenza de llevarlas.

Otro de los propósitos que tuvieron los escritores fue la defensa de la moda para la sociedad, y la importancia de dedicarle un espacio en la prensa local. Es evidente, si comparamos el número de páginas y la periodicidad de este tipo de textos con el contenido misceláneo de las publicaciones en las que fueron incluidos, que era un tema de menor interés para los editores. En las décadas de 1840 a 1860, por ejemplo, las ideas expresadas por los autores destacaban el debate entre los entusiastas de la moda y aquellos que estaban en contra de ella; oposición que también se observa en algunos de los relatos de costumbres y tipos sociales que se publicaron en la prensa local. Uno de los redactores señalaba a sus lectoras que, si bien alguien le había sugerido que el papel y el tiempo invertidos podrían haber sido empleados para hablar de la sal en vez de las modas, él podría demostrarles que "una materia tan interesante" era "el eje de la rueda social" 57 . Tres años después, en el Museo Mexicano, el redactor de modas incluyó esta frase en la que daba cuenta de la pertinencia del tema y las múltiples ramificaciones que le encontraba: "Sería necesario escribir tomos en folio para explicar cuanto observé, medité y discutí sobre tan grave materia: como creía ver a la moda en contacto con la política, relacionada con los placeres domésticos, ramificada con la moral y las conveniencias sociales". ${ }^{58}$

Ligado a lo anterior en los textos de esas décadas se destacó la importancia de que los lectores siguieran los caprichos y exigencias de la moda, para no ser señalados como egoístas, "para no caer en el ridículo de los necios y extravagantes y para no ser el hazme-reír de la sociedad", ${ }^{59}$ así como "porque siendo las modas consecuencia forzosa del lujo [...] preciso es, si hemos de vivir en sociedad, que imitemos a la mayoría apartándonos de los extremos". 60 Es por esta razón que en las páginas de modas existió una tendencia a definir lo que era buen gusto y lo que no, a través de ejemplos, críticas y consejos

57 “Modas”, Museo Yucateco. Periódico Científico y Literario, t. 1, Campeche, 1841, 309.

58 "Modas", El Museo Mexicano o Miscelánea Pintoresca de Amenidades Curiosas e Instructivas, t. 4, México, 1844, 280.

${ }^{59}$ García Montero, "La moda”, Biblioteca de Señoritas. Lecturas de Hogar (Mérida: Imprenta de Rafael Pedrera, 28 de noviembre de 1868, Primera Serie, Entrega 11), 84.

60 “Modas”, El Museo Mexicano o Miscelánea Pintoresca de Amenidades Curiosas e Instructivas, t. 1 México, 1843, 542. 
que destacarían los usos de las prendas y las posibles variantes teniendo en cuenta el contexto local. Veamos en detalle cómo los redactores se movieron entre críticas y elogios alrededor del acto de ataviarse.

\section{Una guía para vestir}

El sistema de la moda daba sentido al proceso de configuración de una nueva estética, de un nuevo código de comportamiento, de una nación en formación. ${ }^{61}$ Las ideas y los comportamientos, sin embargo, no siempre se ajustaban a los significados sociales que permeaban las novedades del atavío y los cuerpos vestidos que las llevaban. En la práctica la aceptación de las modas establecía un rompimiento con el pasado, al menos en lo que a apariencia se refiere, pero el parámetro del buen gusto (buen tono, elegancia, decencia) era el que definía lo adecuado de lo que no lo era en ese proceso de adopción y adaptación de prendas y accesorios. No se trataba de imitar a ciegas; como lo aconsejaba Zafiro, "el buen gusto, ese no sé qué, tan buscado por el sexo bello, y tan rara vez encontrado, no tiene más que un secreto. Saber combinar lo que está de moda con nuestra edad, color y posición. [...] Permanezcan, pues, en un justo medio sencillo y práctico y no desafinar". ${ }^{62}$ La indumentaria en ese sentido tiene relación con nociones sociales y categorías como el tiempo, el espacio y las actividades, el estatus social, las cualidades personales y los valores sociales. ${ }^{63}$ Veamos algunos consejos que les daban los redactores a los yucatecos, consejos que destacan varias de estas nociones en el ámbito local.

Para un redactor de la década de 1840 la abundancia de telas en las tiendas, "de todos dibujos y colores, de toda clase de paños, de casimires, de rasos y de tafetanes, de blondas y muselinas", había significado la pérdida de "nacionalidad o españolismo", ${ }^{64}$ una apreciación que nos parece interesante de destacar si tenemos en cuenta que para esos años las tendencias indumentarias estaban asociadas a los dictados de París como

${ }^{61}$ Atilano, "La moda como práctica cultural y social...", 71.

${ }^{62}$ Zafiro, "Página para las damas", Pimienta y Mostaza. Periódico Literario, de Espectáculos y Variedades, Mérida, 23 de abril de 1893, año II, n. 29, 5. Cursivas en el original.

63 Terence S. Turner, "The social skin”, HAU. Journal of Ethnographic Theory 2, n. 2 (2012).

64 "Modas”, El Museo Mexicano o Miscelánea Pintoresca de Amenidades Curiosas e Instructivas, t. 1, México, 1843, 541. 
epicentro de la moda, así como de ideas políticas y otros referentes culturales vinculados con la modernidad. García, en 1868, afirmaba lo siguiente con respecto a la moda:

¿Y sabéis qué es la moda? La moda no es más que el capricho de un puñado de parisienses del boulevard de los italianos, desde donde promulga su mandato, y ante el cual se doblega la Europa entera e invade hasta la América. La América que ávida a su vez espera su mandato para rendirle también su homenaje. He aquí que todos sin embargo de creer estar libres e independientes, se muestran sumisos obedeciendo el precepto de esa señora que reside en Europa, iqué digo! En una pequeña parte de París. ${ }^{65}$

El redactor de modas del Museo Yucateco le aconsejaba a sus lectoras "que aunque oigan decir, y vean pintado en los figurines, que la moda impone a las señoras el precepto de llevar vestidos tan largos que lleguen a ocultar el pie, no crean que esto habla con ustedes ni con ningún viviente femenino de raza española, porque ustedes en lugar de ocultar los suyos, deben hacer alarde de ellos [...]". ${ }^{66}$ Siguiendo a este autor en el contexto local los pies no debían ocultarse sino destacarse como un don de la naturaleza femenina. En este sentido las modas de los trajes largos rompían con la noción estética y de belleza que se tenía para esos años, aunque es importante aclarar que la mayor parte de la población femenina, es decir, mestizas e indígenas yucatecas, llevaría los pies descubiertos en el caso de que no fueran con zapatos, y en otros dependería del largo del fustán.

En el ir y venir de las formas, destacamos las siguientes ideas alrededor de las variantes que adquieren las prendas y en consecuencia el cuerpo. Es claro que las prendas connotan feminidad o masculinidad en muchos contextos sociales, es decir, que "el género es una construcción cultural que la ropa ayuda a reproducir". ${ }^{67}$ Para los hombres del siglo xix la forma que adquiría el cuerpo femenino a partir de todo lo que sobre él se ponía era un arte que se imponía a las mujeres, para "resaltar sus encantos, o para crear otros nuevos, es un comprobante de su humildad, y el mejor testimonio de que no se creen suficientemente favorecidas por la naturaleza" ${ }^{68}$

${ }^{65}$ García Montero, "La moda”, Biblioteca de Señoritas. Lecturas de Hogar (Mérida: Imprenta de Rafael Pedrera, 1868), 82.

66 “Modas”, Museo Yucateco. Periódico Científico y Literario, t. 1, Campeche, 1841, 309-310.

${ }^{67}$ Entwistle, El cuerpo y la moda..., 28.

${ }^{68}$ Anónimo, "Afeites del tocador", Museo Yucateco. Periódico Científico y Literario, 1842, 78. 
Uno de los ejemplos más dicientes de esto lo encontramos en el artículo "Modas" publicado en el Museo Yucateco, en él su autor refiere cómo

Ahora en nuestro siglo, ligero por excelencia, quiere la moda que el talle de ustedes represente la ligereza misma, de tal suerte que habrá entre ustedes quien crea no tener una cintura fina si esta le cabe en el círculo que forme uniendo los índices y pulgares de sus manos. En una palabra, si una mujer quiere hoy tener un talle de moda, ha de parecerse a una avispa. Y en efecto, ¿̇hay cosa más sutil, más fina que el hilillo o membranita que forma la cintura de una avispa? ¿Hay cosa que indique mejor la ligereza, que un cuerpo dividido en dos partes unidas por un hilo?

Pero si las cabezas, las mangas, y el talle se han estrechado y achicado, no ha sucedido lo mismo con el vuelo del vestido. La elegancia quiere que, elevándose el vestido sobre las caderas, caiga en abundantes pliegues, ensanchándose más y más cada vez hacia abajo de modo que forme campana (voz técnica) [...]. ${ }^{69}$

A pesar de que eran elementos poco prácticos para el clima de la península yucateca, esto no impidió que la crinolina y el corsé fueran utilizados por las damas de la alta sociedad, pues eran unos de los requerimientos de la última moda en los que "tienen fundado todo su lujo y ostentación". ${ }^{70}$ Inclusive fue un estilo que se imitó en el hipil y el fustán de las mestizas, como lo deja ver varias fotografías del Fondo Guerra y una lista de curiosidades que los redactores del $D$. Bullebulle realizaron a lo largo de varios números, en la que aparece "un fustán ${ }^{71}$ a la moda, es decir, tan reciamente almidonado y tan ancho, que sin necesidad de estacas bien pudiera pararse para la tienda de campaña de un general en jefe con toda su plana mayor; lo que no es poco decir". ${ }^{72}$ La moda, de una u otra forma uniformaba a las mujeres de un grupo social exclusivo que se caracterizaría por consumir productos importados para su uso en espacios de socialización, como los bailes, paseos y teatros, en los cuales ostentaban las últimas adquisiciones.

La gente se mueve entre las tendencias de la moda y sus elecciones personales. Con respecto a las mangas, por ejemplo, el redactor de Modas

69 "Modas", Museo Yucateco. Periódico Científico y Literario, 1841, 308.

${ }^{70}$ A. García García, "Inconvenientes del malakoff”, La Guirnalda. Periódico Literario Redactado por una Sociedad de Jóvenes, 1860, 70.

${ }^{71}$ Se refiere a una especie de enagua que se ponen las mujeres yucatecas debajo del hipil.

${ }^{72}$ D. Bullebulle. Periódico Burlesco y de Extravagancias Redactado por una Sociedad de Bulliciosos y de Genios Meridanos (Mérida: Impreso por José María García Morales y por Gabriel V. Gahona, 1847), 232. 
del Museo Yucateco decía "ayer cabían dentro de ellas las personas, hoy con dificultad dan paso al brazo. Pero aquí la moda es aún más indulgente: con tal que la parte superior de la manga que empieza desde el hombro, sea perfectamente ceñida al brazo, el remate depende del gusto de la portadora [...]". ${ }^{73}$ Más adelante advierte que "la moda de que se trata debe ser económica para algunas de ustedes, pues pueden con toda confianza usar las mangas de los vestidos de sus tatarabuelas, si es que éstas les dejaron algunos en su testamento". ${ }^{74}$ Para finales del siglo xix volverían las mangas amplias, como lo deja ver Zafiro que se ensaña contra esa moda:

Los anchos vuelos sobre los hombros, ya sean de encajes o de la tela del traje, imperan hoy con absolutismo, y hay que convenir en que la moda de esta época está más que nunca loca [...] En fin, lo más horrible entre lo horrible, lo más feo, lo más antiestético, lo menos razonable, lo imposible, ésa es la moda actual. Aproximaos, pues, a ella, pero no os acerquéis demasiado [...] Encerrada, pues, en vuestro buen sentido común coged de sus locuras las más apropiadas a vuestro buen juicio, y oponed a sus exagerados mandatos vuestra prudente elegancia y a falta de ésta el temor al ridículo. ${ }^{75}$

En las siguientes fotografías (figuras 5 y 6 ) se puede apreciar la forma de los hombros que se amplía con el uso de encajes y telas a finales del siglo XIX descritos por Zafiro. Esa moda, de acuerdo con la redactora, no sólo era ridícula sino sobre todo quitaba "a la mujer quizá su mejor encanto, cual es lucir su cuerpo más o menos bonito”, pues lo desfigura "haciéndolo desaparecer entre tanto trapo"76. Su comentario permite destacar cómo los discursos y las ideas estéticas en torno a la moda pasan por filtros que aprueban o desaprueban las tendencias al presentar "los trajes como algo hermoso y deseable", ${ }^{77} \mathrm{o}$ en este caso todo lo contrario, como una tendencia que ridiculiza a quien la porta. Siguiendo a Squicciarino, este tipo de atavíos modifican el nivel de percepción general que se tiene del cuerpo en función de la extensión y la forma que adquieran los accesorios y las prendas, pues cambian

73 "Modas", Museo Yucateco. Periódico Científico y Literario, t. 1, Campeche, 1841, 308.

74 “Modas", Museo Yucateco. Periódico Científico y Literario, t. 1, Campeche, 1841, 308.

75 Zafiro, "Página para las damas", Pimienta y Mostaza. Periódico Literario, de Espectáculos y Variedades, Mérida, 23 de agosto de 1893, año II, n. 45, 8.

76 Zafiro, "Página para las damas", Pimienta Y Mostaza. Periódico Literario, de Espectáculos y Variedades, Mérida, 13 de agosto de 1893, año II, n. 45, 8.

77 Entwistle, El cuerpo y la moda..., 59, 60. 


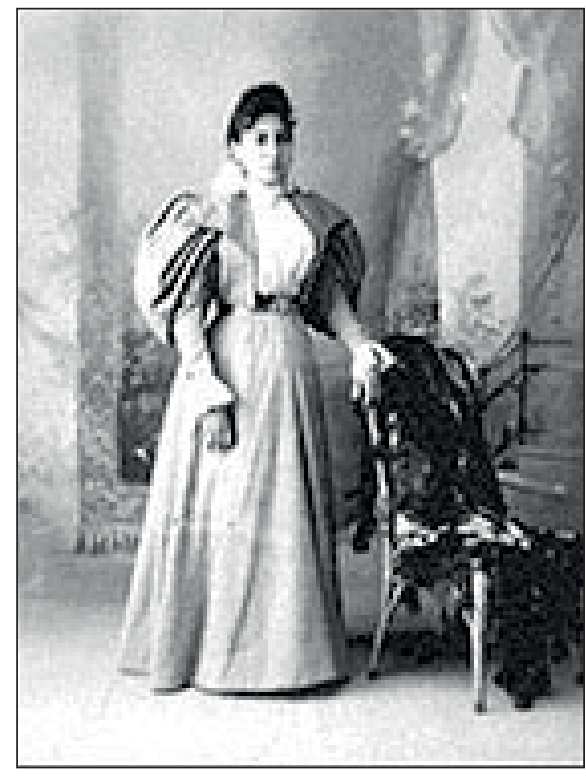

Figura 5. Fototeca Guerra, 2A08_847

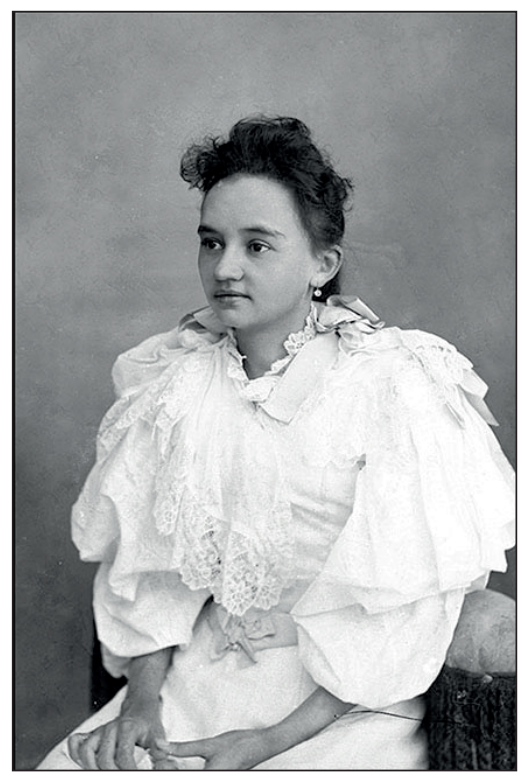

Figura 6. Fototeca Guerra, 2A052938

la apreciación visual y táctil al prolongar la figura. ${ }^{78}$ De esta manera, por ejemplo, ciertas prendas adquieren la cualidad de potenciar la altura, realzar o prolongar una parte del cuerpo, generar distancia frente a los otros. Desde el punto de vista de Zafiro la forma de las mangas no lograba un todo orgánico y armónico entre cuerpo e indumento, sino todo lo contrario, rompía con la estética femenina y terminaba dando un efecto exagerado.

Esa idea de unidad entre cuerpo e indumento como resultado armónico, también la deja ver Peniche en su sección, única redactora que se preocupaba por dar a sus lectoras algunas indicaciones útiles para que destacaran de acuerdo a la forma de su cuerpo. Para evitar la vulgaridad resaltaba la importancia de tener en cuenta la forma del cuerpo a la hora de elegir lo que mejor le quedaba a cada mujer. En cuanto a los colores, recomendaba que los claros los usaran las personas delgadas, "pues la irradiación luminosa de aquellos, contribuye a hacer que parezcan más voluminosas”; los trajes oscuros, en consecuencia "sentarán mejor a las gruesas, pues la absorción de los rayos luminosos hará que aparenten menor volumen”. Los trajes cortos característicos de finales de 1910 y los años 1920, por su parte, “contribuyen

${ }^{78}$ Squicciarino, El vestido habla..., 104, 105. 
a dar apariencia de menos estatura. He aquí por qué las personas altas deben preferirlos y las pequeñas usarlos sin exageración”. Las personas de cuello corto deben evitar el uso de cuello alto o golillas en el traje, pues perjudica su apariencia, "influyendo en sentido contrario dichas prendas en las de hombros caídos y cuello largo”. En cuanto a la cabeza, recomendaba a las mujeres de facciones grandes el uso de adornos, peinados abultados y sombreros de alas, pues rebajaban la estatura; aquellas que tuvieran "cara alargada y cuello no deben jamás usar peinado alto ni llevar los cabellos de adelante echados hacia atrás y ceñidos, descubriéndose por completo la frente y las orejas. Tales peinados sientan mejor en un rostro redondo". ${ }^{79}$

Otro punto que queremos destacar a partir de los textos analizados es el ir y venir de algunas formas en las prendas y, por consiguiente, de la concepción de cuerpo. El redactor del Museo Mexicano no se imaginaba en su momento las posibilidades que el paso del tiempo traería para el atavío, pero ya advertía a sus lectores cómo tendencias anteriores volvían disfrazadas de novedades, tanto en su tiempo como en épocas pasadas. Consideraba que era casi imposible producir

originales, después de tanto como se ha inventado en todos los ramos del saber y de la industria, tenemos que apelar, para hacernos proclamar inventores, o para henchir nuestra bolsa, a los modelos antiguos, que desfiguramos a mansalva como mejor nos place, quitándoles y añadiéndoles a nuestro capricho, para ofrecerlos luego como producciones hijas únicamente de nosotros mismos; es decir, de nuestro talento profundo, o de nuestra imaginación creadora. Por eso se repiten las mismas modas como el pan nuestro de cada día. ${ }^{80}$

En la misma línea está el texto que dedicó Carrillo y Ancona al malakoff. Destacaba que el tontillo, "una especie de faldellín o guarda-pies que usan las mujeres con aros de ballena o de otra materia puestos a trechos para que ahuequen la demás ropa”, es prácticamente lo mismo. En este caso, el cambio de nombre, desde su punto de vista, sólo buscaba darle a "ribetes de progreso y adelantos modernos" ${ }^{81}$ La diferencia entre una y otra prenda

${ }^{79}$ Beatriz Peniche de Ponce, "Página de las damas", Adelante. Seminario Ilustrado de Literatura, Artes y Ciencias, Mérida, 21 de julio de 1917, v. 1, n. 5, 119.

80 "Modas", Museo Yucateco. Periódico Científico y Literario, t, 1, Campeche, 1843, 541.

${ }^{81}$ Crescencio Carrillo y Ancona, "Apuntes históricos sobre el Malakoff”, La Guirnalda. Periódico Literario Redactado por una Sociedad de Jóvenes, 1860, 143. 
era el material del que estaban hechas y el volumen que podían llegar a producir, pero cumplían la misma función.

Lo que ambos autores consideraban falta de imaginación, sin embargo, puede entenderse desde otra perspectiva. Sin duda los factores técnicos influyeron, en parte, en las limitaciones, de forma que podían adquirir las prendas conforme las épocas, y las innovaciones se añadían, más bien, a través de accesorios y detalles. Es por ello que la creatividad alrededor del atavío está presente de forma permanente en la vida cotidiana de las personas; las prendas se arreglan, se renuevan, se modifican para elaborar otras, se adaptan a los distintos cuerpos que las pueden heredar conforme pasa el tiempo. Mercedes Urcelay, a finales del siglo xIx, dio cuenta de parte de la historia vital de un vestido de fiesta al que nombró como "genealogía del famoso vestido":

Blanca Rosa [...] llevó a cabo la completa restauración del traje de familia que ha venido a heredar últimamente. Su primer dueño fue una tía abuela de Blanca, que lo estrenó el mismo día en que hizo su entrada en Mérida la emperatriz Carlota. La cual, según cuenta la fama, se fijó mucho en el tal vestido que entonces era azul pálido. La mamá de Blanca, con aquel ingenio que la hizo tan notable, y con un poco de anilina y algunos ingredientes más, le dio nuevo color y nueva vida. El trabajo de cortar y recortar, de ponerle encajes y perendengues, se encomendó a una habilísima modista muy en boga por aquel entonces. Y salió el vestido tan elegante, confeccionado con arte tan exquisito, que fue admiración y asombro de la escogida concurrencia que llenaba los salones de la "Unión", el 2 de febrero del año de gracia de 1871. Esta es la genealogía del famoso vestido que hoy por hoy es azul pavo, y será negro, según fundadas suposiciones, cuando vaya a dar a manos de la primogénita de Blanca (eso sabe Dios cuándo, porque hasta hoy no le ha salido un mal novio siquiera) ${ }^{82}$

La historia vital del atuendo que presentó Urcelay muestra parte de la trayectoria de la prenda como un objeto heredado entre mujeres de una misma familia que se va adaptando a las tendencias de la moda y al uso que se le va a dar. En este sentido, realiza un ejercicio similar a la biografía cultural de las cosas, en la que hasta donde sea posible se requiere identificar el movimiento de un objeto a lo largo de su vida, es decir, establecer de dónde proviene y quién lo hizo, cuáles han sido sus edades o períodos

${ }^{82}$ Mercedes Urcelay, "Página de las damas", Álbum Literario, Científico de Artes y de Modas, t. I, n. 6, Mérida, 30 de octubre de 1891, 47. 
reconocidos, cómo ha sido usado y qué sucede cuando llega al final de su vida útil. ${ }^{83}$ Este ejemplo sólo es una pequeña muestra de la relación que las personas y en particular las familias tenían, y en menor medida tienen en la actualidad, con la indumentaria. El costo de un vestido en esa época era significativo y su vida útil podía ser muy larga según el uso y cuidado que se tuviera. En el caso de los atuendos festivos las mujeres y hombres tendrían pocos, razón por la cual tiene sentido que se dedicara tiempo a la modificación y renovación, una tarea que se enseñaba a las futuras amas de casa con miras a resguardar la economía del hogar y cumplir con sus obligaciones como madres y esposas. ${ }^{84}$

Si se observa desde el punto de vista del consumo, la moda significó una revolución que orientó el gasto que las personas realizaban sobre su apariencia personal y los valores, comportamientos y prácticas que fueron significando a la indumentaria en la configuración de un nuevo orden social. Desde el siglo Xıx, a través de la publicidad y la prensa especializada se orientaba el gusto por el "último grito de la moda" de mujeres y hombres que acudían a los sastres y modistas o bien de quienes elaboraban las prendas en casa. En este sentido, la moda no es solamente la alta costura, una idea más generalizada para mediados del siglo xIx y especialmente el Xx, que tenía relación con grandes diseñadores y la presentación de las últimas tendencias en pasarelas por las que circulaban modelos vivas y que luego se regularizaría a dos temporadas al año (primavera-verano y otoño-invierno).

\section{Consideraciones finales}

Este primer acercamiento a las secciones y artículos de modas publicados o que circularon en la Península de Yucatán durante la segunda mitad del siglo xix y comienzos del xx, como se ha podido observar, destaca la importancia de estos discursos en los distintos ámbitos locales al estar en relación directa con el sistema de la moda. A través de la palabra y en ocasiones de las imágenes, los escritores instruían a los lectores; no se trataba exclusivamente de describir los trajes y sus usos, sino que muchos aprovecharon el espacio para corregir, sugerir y destacar lo que desde su criterio era válido o no de las tendencias de la moda en el contexto yucateco.

${ }^{83}$ Kopytoff, "La biografía cultural de las cosas...”, 92.

${ }^{84}$ Vanegas, "Virtudes sociales y atavío en Yucatán...". 
Los lectores encontraban en estos textos la intención de la justa medida para no exagerar en cuanto a adornos, uso de telas y combinación de colores y formas, según su cuerpo, su género y su bolsillo. No se trataba, pues, de imitar sin criterio los modelos, sino todo lo contrario, sus redactores esperaban que sus lectores, especialmente las mujeres para las que escribieron la mayor parte de ellos, encontraran en sus descripciones y ejemplos una guía que los orientara en la adquisición del buen gusto. La mayoría de los autores consultados fueron moderados en sus apreciaciones sobre las modas, pues rechazaban aquello que rompe con una estética propia, como fue el caso del largo de los vestidos, la cintura de avispa o las formas de las mangas, que se alejaban del cuerpo femenino vestido por el huipil y el fustán.

Por otro lado, también fueron un referente para motivar el desarrollo de la creatividad de las amas de casa y los artesanos de la moda que en sus páginas encontraban un marco de referencia para conocer tendencias y adaptarlas a su cuerpo, gustos personales y capacidad adquisitiva.

En este breve esbozo se ha destacado, además, la importancia de la prensa como fuente para el estudio histórico de la indumentaria. La moda escrita destaca los debates y particularidades locales, que en ocasiones son semejantes a las de otros contextos, y resaltan el interés cotidiano por el cuerpo, lo que lo viste y lo que significa.

\section{FUENTES}

Hemerografía

Adelante. Seminario Ilustrado de Literatura, Artes y Ciencias

Álbum Literario, Científico de Artes y de Modas

Biblioteca de Señoritas. Lecturas del Hogar

La Guirnalda. Periódico Literario Redactado por una Sociedad de Jóvenes

El Liceo Mexicano

El Museo Mexicano o Miscelánea Pintoresca de Amenidades Curiosas e Instructivas

Museo Yucateco. Periódico Científico y Literario

Pimienta y Mostaza. Periódico Literario, de Espectáculos y Variedades

El Recreo del Hogar 
Bibliografía

Arana López, Gladys N. "Espacios, sujetos y objetos del habitar cotidiano en el México de entre siglos. Mérida la de Yucatán, 1886-1916.” Memoria y Sociedad 17, n. 3 (2013): 236-261.

Armendáriz, Dolores. "La concepción de la moda en México durante el siglo xIx y principios del siglo xx." Nierika. Revista de Estudios de Arte, n. 11 (2017): 26-38. Atilano Villegas, Ruth Yolanda. "La moda como práctica cultural y social en la prensa del Porfiriato: El mundo (1894-1899) y El mundo ilustrado (1900-1914)." Tesis de maestría. Universidad de Guanajuato. 2016.

Barceló, Raquel. "La búsqueda del confort y la higiene en Mérida, 1860-1911.” En Historia de la vida cotidiana en México. V. 4, Bienes y vivencias. El siglo XIX, coordinación de Anne Staples, 213-251. México: El Colegio de México/Fondo de Cultura Económica, 2005.

Barnes, Ruth y Joanne B. Eicher, comps. Dress and Gender: Making and Meaning. Oxford: Berg, 1992.

Bauer, Arnold J. Somos lo que compramos. Historia de la cultura material en América Latina. México: Taurus, 2002.

Bracamontes y Sosa, Pedro. Amos y sirvientes. Las haciendas de Yucatán 1789-1860. Mérida: Universidad Autónoma de Yucatán, 1993.

Braudel, Fernand. Las estructuras de lo cotidiano. Lo posible y lo imposible. Madrid: Alianza Editorial, 1984.

Cruz de Amenábar, Isabel. El traje. Transformaciones de una segunda piel. Santiago: Ediciones Universidad Católica de Chile, 1996.

Duch, Juan. Yucatán en el tiempo. Enciclopedia alfabética. Mérida: Inversiones Cares, 1998.

Entwistle, Joanne. El cuerpo y la moda. Una visión sociológica. Barcelona: Paidós, 2002.

Estrada y Zenea, Ildefonso. Diccionario de los niños. Contiene pensamientos, máximas, consejos e instrucciones relativas a la educación de la juventud, con indicación de las reglas de urbanidad y buenas maneras para la vida social y noticias sobre los más importantes descubrimientos en las ciencias, las artes y las letras. Mérida: Imprenta El Iris de I. E. y Z., 1869.

Fernández, Diana. "Malakoff o crinolina. La actualidad política y la moda." Vestuario escénico, 2015. https://vestuarioescenico.wordpress.com/2015/03/16/ malakoff-o-crinolina-la-actualidad-politica-y-la-moda/.

González Calderón, Marcela. "La imprenta en la península de Yucatán en el siglo xIx." Tesis doctoral. Centro de Investigación y Estudios Superiores en Antropología Social, 2014. 
Guadarrama Olivera, Horacio. "Idelfonso Estrada y Zenea: un intelectual cubano en el puerto de Veracruz, 1871-1872." Sotavento 4, n. 8 (2000): 71-93.

Kopytoff, Igor. "La biografía cultural de las cosas La mercantilización como proceso.” En La vida social de las cosas. Perspectiva cultural de las mercancías, edición de Arjun Appadurai, 89-122. México: Grijalbo, 1991.

Lipovetsky, Gilles. El imperio de lo efímero. La moda y su destino en las sociedades modernas. Barcelona: Anagrama, 1996.

Manrique de Lara, Juana. Seudónimos, anagramas, iniciales, etc., de autores mexicanos y extranjeros. México: Secretaría de Educación Pública, 1943.

Martins, Andreia. "Quimonos chinos y quimones criollos. La moda novohispana en el cruce entre Oriente y Occidente.” En La nao de China, 1565-1815. Navegación, comercio e intercambios culturales, edición de Salvador Bernabéu Albert, 247-280. Sevilla: Universidad de Sevilla, Secretariado de Publicaciones, 2013.

Miranda Ojeda, Pedro. "La modernización de los parques en la ciudad de Mérida, Yucatán (1870-1910).” Letras Históricas, n. 3 (2010): 191-209.

Ortiz, Julieta. Imágenes del deseo. Arte y publicidad en la prensa ilustrada mexicana (1894-1939). México: Universidad Nacional Autónoma de México, Coordinación General de Estudios de Posgrado, 2003.

Pérez, Julieta. “Antes de las secciones y revistas de modas... las modas en el Diario de México." Nierika. Revista de Estudios de Arte, n. 11 (2017): 39-53.

Riello, Giorgio. Breve historia de la moda. Desde la Edad Media hasta la actualidad. Barcelona: Gustavo Gili, 2016.

Roche, Daniel. "La cultura material a través de la historia de la indumentaria." En Historiografía francesa. Corrientes temáticas y metodológicas recientes, edición de Hira de Gortari y Guillermo Zermeño, 77-88. México: Comité Mexicano de Ciencias Históricas, 2000.

Ruz, Mario Humberto. "Del quetzal a la tafeta. Atavío y comercio en la Alcaldía Mayor de Chiapa.” En Gestos cotidianos. Acercamientos etnológicos a los mayas de la época colonial, 151-178. Campeche: Instituto de Cultura de Campeche/ Universidad Autónoma de Campeche/Universidad Autónoma del Carmen/ Instituto Campechano, 1997.

Squicciarino, Nicola. El vestido habla. Consideraciones psico-sociológicas sobre la indumentaria. Madrid: Cátedra, 1998.

Turner, Terence S. "The social skin.” HAU. Journal of Ethnographic Theory 2, n. 2 (2012): 486-504.

Vanegas Durán, Claudia. "Virtudes sociales y atavío en Yucatán a finales del siglo XIX y comienzos del Xx." Estudios de Cultura Maya, n. 53 (2019): 261-287. http://dx.doi.org/10.19130/iifl.ecm.2019.53.971. 
Vega y Ortega Báez, Rodrigo Antonio. "Moral científica para el 'bello sexo' en la prensa mexicana para mujeres (1840-1855)”. Nuevo Mundo Mundos Nuevos, 2010. http://journals.openedition.org/nuevomundo/pdf/60082.

Filmografía

Morgan, Andrew. The true cost. Life Is My Movie Entertainment, 2015, 1 h 32 m.

\section{SOBRE LA AUTORA}

Colombiana. Licenciada en Historia por la Universidad Nacional de Colombia, maestra en Historia por la Pontificia Universidad Javeriana y doctora en Historia por la UNAM. Actualmente realiza una estancia posdoctoral en el Centro de Estudios Mayas del Instituto de Investigaciones Filológicas de esa misma universidad. Sus principales líneas de investigación son el análisis del impacto de la colonización europea en las actividades productivas de los grupos indígenas de los actuales territorios colombiano y mexicano; la cultura material, especialmente los textiles indígenas y la indumentaria; las relaciones de poder en la época colonial y la cultura alimentaria en Latinoamérica. Entre sus publicaciones recientes se encuentran "Virtudes sociales y atavío en Yucatán a finales del siglo xix y comienzos del xx", Estudios de Cultura Maya 53 (2019). 
